\title{
Pengusangan Cepat Fisik serta Penyimpanan Benih Koro Pedang (Canavalia ensiformis (L.) DC.) Menggunakan Ruang Simpan dan Kemasan Berbeda
}

\author{
Physical Accelerated Aging Test and Storaged of Jack Bean Seed (Canavalia ensiformis (L.) DC.) Using \\ Different Storage Room and Packaging Materials
}

\author{
Naning Emilia Rahmawati, Tatiek Kartika Suharsi*, Memen Surahman
}

Departemen Agronomi dan Hortikultura, Fakultas Pertanian, Institut Pertanian Bogor (Bogor Agricultural University), Jl. Meranti, Kampus IPB Darmaga, Bogor 16680, Indonesia Telp. \& Faks.62-251-8629353 e-mail agronipb@indo.net.id

*Penulis untuk korespondensi: t.suharsi@yahoo.co.id

Disetujui 14 November 2016/Published online 8 Desember 2016

\begin{abstract}
Environment of storage conditions (temperature and $R H$ ) and type of packaging are important factors affecting seed storability. The aim of this research was to determine physical accelerated aging effect to jack bean seed viability and vigor, get the right storage room and pakaging materials to maintain seed viability and vigor during storage. The research consisted of 2 experiments. Experiment I using Randomize Complete Block Design with physical aging periods as a factor, which consisted of 0, 30, 60, 90, 120, 150, and 180 minutes aging periode. Experiment II using a nested design with two factors. The first factor was storage room that consist of ambient storage condition and air-conditioned room. The second factor was packaging materials that consists of 3 levels i.e plastic bags, plastic jerrycans, and plastic polypropylene. The results of experiment I showed that phyisical accelerated aging with high temperature and humidity effectively decrease the viability and vigor as well as increase the moisture content of jack bean seed. Experiment 2 showed that the jack been seed storage in ambient storage condition produce higher moisture content, viability, and vigor than storage in air-conditioned room. Jack bean seed storage using plastic bags produce higher moisture content, viability, and vigor than storage using plastic jerrycans, and plastic polypropylene.
\end{abstract}

Keywords: aging periods, seed moisture content, seed viability, seed vigor, storage period

\section{ABSTRAK}

Kondisi lingkungan simpan (suhu dan $R H$ ) dan jenis kemasan merupakan faktor penting yang mempengaruhi daya simpan benih. Tujuan penelitian ini adalah untuk mengetahui pengaruh pengusangan cepat secara fisik terhadap viabilitas dan vigor benih koro pedang serta mendapatkan ruang simpan dan jenis kemasan yang tepat untuk mempertahankan viabilitas dan vigor benih koro pedang selama penyimpanan. Penelitian terdiri atas 2 percobaan. Percobaan I menggunakan Rancangan Kelompok Lengkap Teracak dengan lama penderaan fisik sebagai faktornya, yang terdiri atas 0, 30, 60, 90, 120, 150, dan 180 menit. Percobaan II menggunakan rancangan percobaan tersarang dengan 2 faktor. Faktor pertama berupa ruang simpan yang terdiri atas ruang suhu kamar dan ruang ber-AC. Faktor kedua jenis kemasan yang terdiri atas 3 taraf yaitu karung plastik, jerigen plastik, dan plastik polypropylene. Hasil percobaan I menunjukkan bahwa penderaan fisik dengan suhu dan RH tinggi efektif menurunkan viabilitas dan vigor benih serta meningkatkan kadar air benih koro pedang. Hasil Percobaan II menunjukkan bahwa penyimpanan benih koro pedang pada ruang suhu kamar menghasilkan kadar air, viabilitas, dan vigor benih lebih tinggi dibandingkan penyimpanan pada ruang ber-AC. Penyimpanan benih koro pedang dengan karung plastik menghasilkan kadar air, viabilitas, dan vigor benih lebih tinggi dibandingkan dengan penyimpanan dengan jerigen plastik dan plastik polypropylene.

Kata kunci: kadar air benih, lama penderaan, periode simpan, viabilitas benih, vigor benih 


\section{PENDAHULUAN}

Tanaman kacang-kacangan (anggota famili Leguminosae) merupakan sumber makanan penting kedua setelah serealia. Leguminosae memiliki 600 genus dan 12000 spesies, tetapi hanya 25 spesies yang saat ini dikonsumsi secara luas (Ashworth, 2002). Fakta ini memberikan peluang yang sangat besar dalam pengembangan kacang-kacangan di Indonesia. Masih banyak jenis kacang-kacangan di Indonesia yang belum populer di masyarakat tetapi memiliki banyak manfaat, salah satunya adalah koro pedang (Canavalia ensiformis (L.) DC). Pengembangan koro pedang di Indonesia memiliki tujuan utama untuk mengurangi kebutuhan kedelai di Indonesia. Kebutuhan Indonesia terhadap kedelai sekitar 2.2 juta ton/ tahun, namun produksi kedelai Indonesia hanya mampu memenuhi 30 sampai $40 \%$ dari kebutuhan nasional tersebut. Oleh karena itu, perlu dikembangkan komoditas lain yang dapat digunakan sebagai substitusi kedelai. Salah satu komoditas yang berpeluang adalah koro pedang yang mudah dibudidayakan secara monokultur maupun tumpang sari serta adaptif pada lahan kering (Puslitbangtan, 2007).

Produksi koro pedang di Indonesia masih terpusat di beberapa daerah, diantaranya: Kebumen, Grobogan, Jember, Bogor, NTB, dan Sulawesi Selatan sehingga perlu adanya sosialisasi untuk lebih mengenalkan koro pedang di Indonesia. Hal ini bertujuan untuk meningkatkan produksi koro pedang, sehingga koro pedang dapat digunakan sebagai salah satu bahan pangan subtitusi kedelai. Tingginya impor kedelai di Indonesia diharapkan mampu dikurangi dengan adanya produksi koro pedang ini. Peluang pengembangan koro pedang masih terbuka luas diantaranya melalui perluasan area tanam baru, Peningkatan Indeks Pertanaman (PIP), tersedianya paket teknologi baru, benih unggul bermutu serta peluang pasar yang cukup besar akibat meningkatnya kebutuhan konsumsi dan berkembangnya industri olahan (susu, tahu, mie, minyak, biskuit, selai, bubur, dan kosmetik) (Dirjen TP, 2013).

Penyediaan benih dalam jumlah besar mengakibatkan adanya stok benih di gudang penyimpanan, sehingga benih harus mengalami penyimpanan. Faktor terpenting yang mempengaruhi periode hidup benih dalam penyimpanan adalah kadar air dan suhu. Pemilihan jenis kemasan dan kondisi ruang simpan yang tepat diharapkan mampu mempertahankan kadar air dan suhu yang optimal untuk penyimpanan benih. Selain untuk mempertahankan viabilitas benih, pemilihan jenis kemasan juga harus disesuaikan dengan kebutuhan pasar, mudah didapatkan, dan ekonomis.

Vigor daya simpan merupakan suatu parameter vigor benih yang ditunjukkan dengan kemampuan benih untuk disimpan dalam keadaan suboptimum. Salah satu cara simulasi vigor daya simpan benih dilakukan dengan metode pengusangan cepat. Metode ini dapat menduga vigor daya simpan secara cepat dan akurat. Penelitian mengenai pengusangan cepat pada tanaman kacang-kacangan sudah dilakukan pada beberapa komoditas, diantaranya kedelai dan kacang tanah. Viabilitas dan vigor benih kedelai dan kacang tanah semakin menurun seiring dengan penambahan waktu pengusangan. Pengujian pengusangan pada benih koro pedang diharapkan bisa menunjukkan hasil seperti pengujian pada benih kedelai dan benih kacang tanah. Penelitian ini bertujuan untuk mengetahui pengaruh pengusangan cepat fisik terhadap viabilitas dan vigor benih koro pedang serta mendapatkan ruang simpan dan jenis kemasan yang tepat dalam mempertahankan viabilitas dan vigor benih koro pedang selama penyimpanan.

\section{BAHAN DAN METODE}

Penelitian dilaksanakan di Laboratorium Ilmu dan Teknologi Benih dan Kebun Percobaan Leuwikopo, Departemen Agronomi dan Hortikultura, Fakultas Pertanian, Institut Pertanian Bogor. Penelitian dilaksanakan mulai bulan Januari sampai dengan Juli 2014.

Bahan yang digunakan dalam penelitian ini adalah benih koro pedang yang dipanen bulan September 2012 dari lahan Kebun Percobaan Leuwikopo, karung plastik $(11 \mathrm{~cm}$ x $23 \mathrm{~cm})$, jerigen plastik $(1 \mathrm{~L})$, dan plastik polypropylene $(15 \mathrm{~cm} \times 21 \mathrm{~cm} \times 0.08 \mathrm{~cm})$ sebagai kemasan, media pasir untuk mengecambahkan benih, benang jahit dan kertas label. Alat- alat yang digunakan meliputi alat pengusangan cepat (APC) tipe IPB 77-1 MMM, peralatan untuk mengukur kadar air (oven $103 \pm 2{ }^{\circ} \mathrm{C}$, timbangan analitik, dan desikator), bak plastik untuk tempat pengecambahan benih, alat perekat kemasan (sealer), jarum jahit, gunting pangkas, dan pengukur RH dan suhu (hygro-thermometer).

Penelitian terdiri atas 2 percobaan, percobaan I dilakukan untuk mengetahui pengaruh pengusangan cepat secara fisik terhadap viabilitas dan vigor benih koro pedang. Rancangan percobaan yang digunakan ialah rancangan kelompok lengkap teracak (RKLT). Faktor perlakuan berupa lama penderaan $(\mathrm{P})$ yang 
terdiri atas 7 taraf, yaitu 0 menit (P0), 30 menit (P1), 60 menit (P2), 90 menit (P3), 120 menit (P4), 150 menit (P5), dan 180 menit (P6). Masingmasing taraf terdiri atas 3 ulangan, sehingga pada percobaan ini ada 21 satuan percobaan. Setiap percobaan terdiri atas $200 \mathrm{~g}$ benih. Tahap awal dari pelaksanaan percobaan pertama yaitu meningkatkan kadar air benih hingga $20 \%$. Peningkatan kadar air dilakukan dengan memasukkan benih kedalam plastik PP yang sudah diberi air, kemudian dimasukkan ke dalam refrigerator suhu $5{ }^{\circ} \mathrm{C}$ selama $20 \mathrm{jam}$. Benih yang sudah dilembabkan, kemudian dimasukkan ke dalam alat pengusangan cepat (APC) IPB 77-1 MMM sesuai waktu perlakuan. Benih yang sudah selesai diberi perlakuan kemudian diuji viabilitas dan kadar airnya. Tahap terakhir ialah pengujian dan pengamatan.

Percobaan II dilakukan untuk mendapatkan ruang simpan dan jenis kemasan yang tepat dalam mempertahankan mutu benih koro pedang selama penyimpanan. Penyimpanan benih pada percobaan ini dilakukan selama 6 bulan pada 2 ruang simpan dan 3 jenis kemasan yang berbeda. Percobaan ini menggunakan Rancangan Tersarang (nested design) dengan 2 faktor perlakuan. Faktor pertama berupa ruang simpan (R) yang terdiri atas 2 taraf perlakuan yaitu ruang suhu kamar (R1) dan ruang ber-AC (R2). Faktor kedua adalah jenis kemasan (K) yang terdiri atas 3 taraf perlakuan yaitu karung plastik (K1), jerigen plastik (K2), dan plastik polypropylene (K3). Total kombinasi perlakuan ada 6 kombinasi dengan masing-masing perlakuan terdiri atas 3 ulangan dan pengamatan dilakukan 6 kali sehingga terdapat 108 satuan percobaan. Tolok ukur yang diamati untuk masing-masing percobaan terdiri atas: pengujian kadar air (KA), potensi tumbuh maksimum (PTM), daya berkecambah (DB), berat kering kecambah normal (BKKN), indeks vigor (IV), kecepatan tumbuh $\left(\mathrm{K}_{\mathrm{CT}}\right)$, dan keserempakan tumbuh $\left(\mathrm{K}_{\mathrm{ST}}\right)$.

Data hasil percobaan yang diperoeh diuji dengan uji $F$ pada aplikasi SAS dan jika terdapat pengaruh yang nyata, maka akan dianalisis dengan uji lanjut menggunakan Duncan Multiple Range Test (DMRT) pada taraf $\alpha=5 \%$.

\section{HASIL DAN PEMBAHASAN}

\section{Kondisi Umum}

Benih koro pedang yang digunakan pada kedua percobaan ini berasal dari lahan Kebun Percobaan Leuwikopo yang dipanen pada bulan September 2012. Informasi mengenai viabilitas awal benih sangat diperlukan dalam penelitian ini, terutama untuk percobaan penyimpanan benih. Data kadar air dan viabilitas benih sebelum perlakuan terdapat pada Tabel 1. Kondisi awal benih koro pedang sebelum perlakuan memiliki kadar air $9.31 \%$ dan daya berkecambah $95.60 \%$. Kadar air dan daya berkecambah tersebut sesuai dengan persyaratan standar kelulusan sertifikasi benih tanaman pangan, yaitu kadar air benih koro pedang maksimal $12 \%$ dan daya berkecambah minimal 70\% untuk semua kelas benih (Dirjen TP, 2009).

Tabel 1. Kadar air dan viabilitas awal benih koro pedang sebelum perlakuan

\begin{tabular}{lc}
\hline Tolok ukur & Nilai \\
\hline Kadar air (\%) & 9.31 \\
Potensi tumbuh maksimum (\%) & 98.80 \\
Daya berkecambah (\%) & 95.60 \\
Berat kering kecambah normal $(\mathrm{g})$ & 24.55 \\
Indeks vigor (\%) $_{\text {Kecepatan tumbuh (\% etmal }^{-1} \text { ) }}$ & 47.80 \\
Keserempakan tumbuh (\%) $^{2}$ & 17.64 \\
\hline
\end{tabular}

Percobaan I: Pengusangan Cepat Fisik Benih Koro Pedang

Penyimpanan benih harus dilakukan jika ketersediaan benih berlebih. Selama periode simpan, benih harus dipertahankan mutunya. Kemampuan benih untuk mempertahankan mutu selama penyimpanan diamati berdasarkan tolok ukur kadar air benih, potensi tumbuh maksimum, viabilitas benih (daya berkecambah dan berat kering kecambah normal), dan vigor benih (indeks vigor, kecepatan tumbuh, dan keserempakan tumbuh). Salah satu metode untuk menguji mutu benih adalah pengusangan cepat benih secara fisik. Pengusangan cepat benih secara fisik dapat dilakukan dengan mendera benih pada kondisi suhu dan RH yang tinggi.

Perlakuan lama penderaan pada penelitian ini berpengaruh sangat nyata terhadap kadar air (KA) benih dan viabilitas benih dengan tolok ukur daya berkecambah (DB). Lama penderaan berpengaruh nyata terhadap tolok ukur potensi tumbuh maksimum dan vigor benih dengan tolok ukur kecepatan tumbuh $\left(\mathrm{K}_{\mathrm{CT}}\right)$. Lama penderaan tidak berpengaruh nyata pada tolok ukur BKKN, IV dan $\mathrm{K}_{\mathrm{ST}}$.

Percobaan I menunjukkan kadar air setelah pengusangan cenderung terus meningkat sejalan dengan meningkatnnya lama penderaan. Benih yang diberi perlakuan lama penderaan 120, 150 dan 180 menit memiliki kadar air yang sangat tinggi (Tabel 2). Alat pengusangan dengan kondisi suhu $40{ }^{\circ} \mathrm{C}$ dan $\mathrm{RH}$ yang mencapai $90 \%$ menyebabkan benih mengalami peningkatan 
kadar air yang signifikan. Mustika et al. (2014) menyatakan peningkatan kadar air benih kedelai setelah pengusangan dikarenakan benih bersifat higrokopis sehingga benih kedelai dapat menyerap air dari udara sekitar.

Tolok ukur potensi tumbuh maksimum menunjukkan jumlah benih yang tumbuh, baik menjadi kecambah normal maupun abnormal. Benih koro pedang yang mengalami penderaan selama 180 menit memiliki potensi tumbuh maksimum paling rendah sebesar $79.33 \%$ tetapi tidak berbeda nyata dengan benih yang didera selama 90 dan 120 menit (Tabel 2). Potensi tumbuh maksimum cenderung turun sejalan dengan meningkatnnya lama penderaan. Penelitian Imaniar (2012) pada benih kedelai juga menunjukkan semakin lama waktu penderaan maka potensi tumbuh maksimun akan semakin turun.

Menurunnya nilai PTM sejalan dengan meningkatnnya lama penderaan diduga karena tingginya kadar air benih yang sudah diusangkan. Benih dengan kadar air yang tinggi akan cepat terserang hama penyakit ketika dikecambahkan. Hal inilah yang diduga sebagai penyebab rendahnya PTM pada benih dengan penderaan 180 menit (79.33\%) (Tabel 2). Benih yang sudah terserang hama penyakit akan mati atau tumbuh dengan kondisi abnormal. Kecambah abnormal yang banyak ditemukan dari hasil pengusangan cepat ini antara lain: kecambah busuk, akar primer tidak tumbuh atau busuk, kotiledon busuk, dan panjang hipokotil kurang dari 2 kali panjang benih.

Tabel 2. Pengaruh lama penderaan terhadap kadar air, potensi tumbuh maksimum, viabilitas dan vigor benih koro pedang

\begin{tabular}{clllclcc}
\hline $\begin{array}{c}\text { Lama } \\
\text { penderaan } \\
\text { (Menit) }\end{array}$ & KA $(\%)$ & PTM $(\%)$ & DB $(\%)$ & BKKN $(\%)$ & IV $(\%)$ & $\begin{array}{c}\mathrm{K}_{\mathrm{CT}} \\
(\% / \text { etmal })\end{array}$ & $\mathrm{K}_{\text {ST }}(\%)$ \\
\hline 0 & $9.06 \mathrm{~d}$ & $98.67 \mathrm{a}$ & $94.00 \mathrm{a}$ & 19.70 & 40.00 & $16.78 \mathrm{a}$ & 31.33 \\
30 & $15.52 \mathrm{dc}$ & $90.00 \mathrm{ab}$ & $74.00 \mathrm{~b}$ & 17.70 & 38.00 & $13.51 \mathrm{ab}$ & 27.33 \\
60 & $18.10 \mathrm{bc}$ & $90.00 \mathrm{ab}$ & $78.00 \mathrm{~b}$ & 20.15 & 43.33 & $14.38 \mathrm{ab}$ & 30.00 \\
90 & $17.15 \mathrm{c}$ & $87.33 \mathrm{bc}$ & $68.67 \mathrm{bc}$ & 17.32 & 38.00 & $12.60 \mathrm{bc}$ & 26.33 \\
120 & $24.21 \mathrm{ab}$ & $84.00 \mathrm{bc}$ & $73.00 \mathrm{bc}$ & 16.03 & 41.33 & $12.67 \mathrm{bc}$ & 27.33 \\
150 & $26.09 \mathrm{a}$ & $94.00 \mathrm{ab}$ & $76.00 \mathrm{~b}$ & 16.03 & 50.00 & $14.30 \mathrm{ab}$ & 28.67 \\
180 & $26.36 \mathrm{a}$ & $79.33 \mathrm{c}$ & $60.68 \mathrm{c}$ & 13.91 & 34.00 & $11.11 \mathrm{c}$ & 23.33 \\
\hline
\end{tabular}

Keterangan: Angka-angka pada kolom yang sama yang diikuti oleh huruf yang sama tidak berbeda nyata pada taraf uji $5 \%$ (uji selang berganda Duncan) ; KA: kadar air; PTM: potensi tumbuh maksimum; DB: daya berkecambah; BKKN: berat kering kecambah normal; IV: indeks vigor; $\mathrm{K}_{\mathrm{CT}}$ : kecepatan tumbuh; $\mathrm{K}_{\mathrm{ST}}$ : keserempakan tumbuh

Penurunan viabilitas benih yang diberi perlakuan pengusangan ditunjukkan dengan tolok ukur daya berkecambah. Daya berkecambah benih yang tidak mengalami penderaan sebesar $94.00 \%$, setelah didera selama 180 menit daya berkecambah benih koro pedang hanya $60.68 \%$ (Tabel 2). Daya berkecambah cenderung terus menurun sejalan dengan meningkatnnya lama penderaan. Hasil penelitian Imaniar (2012) pada benih kedelai juga menunjukkan semakin lama waktu pengusangan maka daya berkecambahnya akan semakin rendah.

Penurunan vigor benih karena pengusangan dapat dilihat dari tolok ukur kecepatan tumbuh yang cenderung mengalami penurunan setelah benih didera secara fisik. Kecepatan tumbuh benih koro pedang yang sebelum didera sebesar $16.78 \%$ etmal $^{-1}$, setelah mengalami penderaan selama 180 menit $\mathrm{K}_{\mathrm{CT}}$ benih koro pedang tinggal $11.11 \%$ etmal $^{-1}$ (Tabel 2). Sesuai dengan penelitian Badriah (2012) yang menunjukkan adanya keeratan hubungan antara lama waktu pengusangan fisik dengan tolok ukur vigor benih jagung. Semakin lama waktu pengusangan benih jagung di APC tipe IPB 77-1 MM, tolok ukur indeks vigor dan kecepatan tumbuh benih jagung semakin menurun.

Perlakuan lama penderaan tidak berpengaruh terhadap tolok ukur indeks vigor dan keserempakan tumbuh benih koro pedang. Hal ini diduga karena benih koro pedang yang digunakan memiliki vigor benih yang sudah rendah. Tolok ukur indeks vigor dan keserempakan tumbuh mengalami penurunan selama penderaan, tetapi lama penderaan tidak memberikan pengaruh yang nyata pada kedua tolok ukur tersebut. Masih adanya penurunan vigor benih akibat lama penderaan dapat diketahui karena lama penderaan berpengaruh nyata terhadap tolok ukur kecepatan tumbuh.

\section{Percobaan II : Penyimpanan Benih Koro Pedang Menggunakan Kemasan dan Ruang Simpan Berbeda}

Perlakuan ruang simpan dan jenis kemasan berpengaruh sangat nyata terhadap kadar air benih koro pedang selama penyimpanan 6 bulan. 
Pengamatan tolok ukur potensi tumbuh maksimum memberikan hasil yang berbeda dengan pengamatan kadar air benih. Potensi tumbuh maksimum tidak dipengaruhi oleh ruang simpan dan jenis kemasan selama penyimpanan, kecuali pada periode simpan 2 bulan. Jenis kemasan berpengaruh sangat nyata terhadap potensi tumbuh maksimum pada periode simpan 2 bulan.

Hasil pengamatan daya berkecambah benih hampir sama dengan tolok ukur potensi tumbuh maksimum. Ruang simpan dan jenis kemasan tidak berpengaruh nyata terhadap daya berkecambah benih selama periode 1-5 bulan simpan. Periode simpan 6 bulan, ruang simpan dan jenis kemasan berpengaruh nyata pada tolok ukur daya berkecambah. Ruang simpan dan jenis kemasan berpengaruh sangat nyata terhadap tolok ukur indeks vigor selama periode $1-5$ bulan simpan, kecuali pada periode simpan 5 bulan. Ruang simpan tidak berpengaruh nyata terhadap indeks vigor pada periode simpan 5 bulan. Ruang simpan dan jenis kemasan tidak memberikan pengaruh yang nyata terhadap tolok ukur indeks vigor pada periode simpan 6 bulan.

Pengaruh Ruang Simpan terhadap Kadar Air, Potensi Tumbuh Maksimum, Viabilitas, dan Vigor Benih Koro Pedang

Kadar air benih yang disimpan di ruang suhu kamar nyata lebih tinggi dibandingkan dengan kadar air benih yang disimpan di ruang ber-AC selama penyimpanan 6 bulan. Kadar air benih yang disimpan di ruang suhu kamar berkisar $10.69 \%-11.40 \%$ sedangkan kadar air benih yang disimpan di ruang ber-AC berkisar antara $8.27 \%$ 9.32\% (Tabel 3) . Hal ini disebabkan pada kondisi kamar selama penyimpanan menunjukkan suhu dan $\mathrm{RH}$ cukup tinggi (suhu $23.3-29.9{ }^{\circ} \mathrm{C}$ dan $\mathrm{RH}$ 61-85\%) sedangkan pada kondisi ruang ber-AC menunjukkan suhu dan RH lebih rendah (suhu 16.3 - $26.3{ }^{\circ} \mathrm{C}$ dan $\left.\mathrm{RH} 33-69 \%\right)$. Rahayu dan Widajati (2007) dari hasil penelitian terhadap benih caisin menyimpulkan hal yang sama, kadar air benih caisin yang disimpan pada kondisi kamar memiliki kadar air rata-rata nyata lebih tinggi dibandingkan dengan kondisi ruang AC.

Potensi tumbuh maksimum (PTM) merupakan total benih yang menunjukkan gejala pertumbuhan, dengan kata lain PTM merupakan gambaran dari benih yang mampu tumbuh menjadi kecambah normal maupun abnormal (Saleh dan Wardah, 2010). Potensi tumbuh maksimum benih koro pedang secara statistik tidak dipengaruhi ruang simpan selama penyimpanan 6 bulan. Selama penyimpanan, potensi tumbuh maksimum mengalami fluktuasi tetapi tetap bertahan di atas $90 \%$. Potensi tumbuh maksimum benih yang disimpan diruang kamar antara $95.33 \%$ - $100 \%$ dan benih yang disimpan di ruang ber-AC memiliki nilai potensi tumbuh maksimum 93.78\% - 99.78\% (Tabel 3). Berbeda dengan hasil penelitian Baktisari (2011) terhadap benih kedelai, potensi tumbuh maksimum pada periode simpan 1 bulan mulai mengalami penurunan antara $72 \%$ - 97\%. Potensi tumbuh maksimum pada periode simpan 3 bulan mengalami penurunan tajam sehingga nilainya kurang dari $45 \%$. Benih koro pedang mampu mempertahankan potensi tumbuh maksimum hingga akhir periode simpan diduga karena kulit benih yang tebal dan keras mampu melindungi benih ketika disimpan.

Faktor ruang simpan tidak berpengaruh nyata terhadap tolok ukur daya berkecambah benih koro pedang selama periode 1- 5 bulan simpan, dengan DB masih bertahan di atas $90 \%$. Daya berkecambah benih diruang kamar lebih tinggi daripada daya berkecambah benih di ruang ber-AC pada periode simpan 6 bulan. Daya berkecambah benih pada periode simpan 6 bulan ini megalami penurunan yang sangat signifikan hingga mencapai $67.11 \%$ pada ruang kamar dan $53.11 \%$ pada ruang ber-AC (Tabel 3). Hasil penelitian Muchtar et al. (2014) menunjukkan benih jagung manis tanpa perlakuan coating (kontrol) mengalami penurunan yang sangat signifikan. Periode simpan 0 bulan daya berkecambah $82.7 \%$ dan daya berkecambah turun menjadi 56.7\% pada periode simpan 24 minggu. Penurunan DB yang sangat signifikan pada periode simpan 6 bulan, sedangkan PTM benih yang masih bertahan diatas 90\% (Tabel 3) memperlihatkan bahwa pada akhir penyimpanan ini banyak sekali benih yang tumbuh menjadi kecambah abnormal. Tabel 3 menunjukkan PTM benih di ruang kamar sebesar $95.33 \%$ dan DB sebesar $55.56 \%$, dari data ini dapat dilihat bahwa $39.77 \%$ dari 50 benih tumbuh abnormal. Hasil tersebut juga mengindikasikan bahwa viabilitas benih koro pedang sudah turun pada periode simpan 6 bulan.

Berat kering kecambah normal benih yang disimpan di ruang kamar lebih tinggi dibandingakan dengan berat kering kecambah normal yang disimpan di ruang ber-AC pada periode simpan 1 dan 3 bulan. Selama penyimpanan 1 - 4 bulan, berat kering kecambah normal cenderung tetap di atas $20 \mathrm{~g}$, mulai turun pada periode simpan 5 bulan dan turun secara signifikan pada periode simpan 6 bulan (Tabel 3). 
Tabel 3. Pengaruh ruang simpan terhadap kadar air, potensi tumbuh maksimum, viabilitas, dan vigor benih koro pedang selama periode simpan 1-6 bulan

\begin{tabular}{|c|c|c|c|c|c|c|c|}
\hline \multirow[b]{2}{*}{ Ruang simpan } & \multicolumn{7}{|c|}{ Tolok ukur ${ }^{\mathrm{a}}$} \\
\hline & $\begin{array}{l}\text { KA } \\
(\%)\end{array}$ & $\begin{array}{c}\text { PTM } \\
(\%)\end{array}$ & $\begin{array}{l}\text { DB } \\
(\%)\end{array}$ & BKKN (g) & IV $(\%)$ & $\begin{array}{c}\mathrm{K}_{\mathrm{CT}} \\
\left(\% \text { etmal }^{-1}\right)\end{array}$ & $\begin{array}{l}\mathrm{K}_{\mathrm{ST}} \\
(\%)\end{array}$ \\
\hline & & & & 1 bulan & & & \\
\hline Ruang kamar & $10.83 a$ & 99.33 & 96.67 & $23.97 \mathrm{a}$ & $52.00 \mathrm{a}$ & 17.70 & 54.22 \\
\hline Ruang ber-AC & $9.32 b$ & 99.11 & 96.89 & $\begin{array}{c}20.64 \mathrm{~b} \\
2 \text { bulan }\end{array}$ & $33.78 \mathrm{~b}$ & 17.11 & 55.11 \\
\hline Ruang kamar & $11.40 \mathrm{a}$ & 99.78 & 94.44 & 20.64 & $44.56 \mathrm{a}$ & 16.95 & $47.33 \mathrm{a}$ \\
\hline Ruang ber-AC & $9.13 b$ & 99.11 & 93.78 & $\begin{array}{r}19.00 \\
3 \text { bulan }\end{array}$ & $32.22 b$ & 16.29 & $29.33 b$ \\
\hline Ruang kamar & $11.21 \mathrm{a}$ & 100.00 & 94.00 & $23.32 \mathrm{a}$ & $51.11 \mathrm{a}$ & $17.29 \mathrm{a}$ & $66.89 a$ \\
\hline Ruang ber-AC & $8.96 \mathrm{~b}$ & 99.78 & 92.89 & $\begin{array}{c}21.62 b \\
4 \text { bulan }\end{array}$ & $24.44 b$ & $16.03 b$ & $42.22 b$ \\
\hline Ruang kamar & $10.69 \mathrm{a}$ & 98.89 & 92.44 & 25.11 & $42.67 \mathrm{a}$ & $16.68 \mathrm{a}$ & $35.78 \mathrm{a}$ \\
\hline Ruang ber-AC & $8.27 \mathrm{~b}$ & 98.44 & 90.00 & $\begin{array}{r}23.83 \\
5 \text { bulan }\end{array}$ & $27.78 \mathrm{~b}$ & $15.67 \mathrm{~b}$ & $26.67 b$ \\
\hline Ruang kamar & $10.69 a$ & 96.20 & 90.44 & 19.66 & 20.44 & 15.33 & 22.44 \\
\hline Ruang ber-AC & $9.10 \mathrm{~b}$ & 98.67 & 90.00 & $\begin{array}{r}19.58 \\
6 \text { bulan }\end{array}$ & 15.11 & 15.21 & 13.11 \\
\hline Ruang kamar & $11.06 \mathrm{a}$ & 95.33 & $55.56 \mathrm{a}$ & 11.49 & 4.67 & $11.12 \mathrm{a}$ & 15.78 \\
\hline Ruang ber-AC & $9.27 \mathrm{~b}$ & 93.78 & $46.78 b$ & 9.66 & 1.56 & $8.09 \mathrm{~b}$ & 6.89 \\
\hline
\end{tabular}

Keterangan: Angka-angka pada kolom yang sama yang diikuti oleh huruf yang sama pada bulan pengamatan yang sama tidak berbeda nyata pada taraf uji 5\% (uji selang berganda Duncan) ; KA: kadar air; PTM: potensi tumbuh maksimum; DB: daya berkecambah; BKKN: berat kering kecambah normal; IV: indeks vigor; КСт : kecepatan tumbuh; KsT: keserempakan tumbuh

Syarovi et al. (2013) menyatakan benih yang memiliki daya berkecambah tinggi akan memiliki bobot kering kecambah normal yang tinggi pula. Pernyataan ini sesuai dengan hasil penelitian yang bisa dilihat pada Tabel 3 , bahwa benih yang memiliki DB tinggi maka BKKN-nya juga cenderung lebih tinggi.

Faktor ruang simpan memberikan pengaruh yang berbeda-beda terhadap tolok ukur vigor benih yang terdiri atas: $\mathrm{IV}, \mathrm{K}_{\mathrm{CT}}$, dan $\mathrm{K}_{\mathrm{ST}}$ selama periode simpan 1 sampai 6 bulan (Tabel 3). Indeks vigor benih koro pedang yang disimpan di ruang kamar lebih tinggi dibandingkan yang di ruang ber-AC pada periode simpan 1 sampai 4 bulan, dan pada periode simpan 2, 5, dan 6 bulan tidak berbeda nyata. Kadar air benih yang tinggi pada ruang kamar (Tabel 3) diduga menyebabkan benih mengalami laju respirasi lebih cepat sehingga laju pertumbuhan lebih cepat pula. Laju pertumbuhan yang cepat mengakibatkan nilai IV benih yang disimpan di ruang kamar menjadi lebih tinggi dibandingkan dengan ruang ber-AC. Indeks vigor pada kedua ruang simpan terus menurun, dan pada periode simpan 6 bulan tinggal $4.67 \%$ pada ruang kamar dan $1.56 \%$ pada ruang ber-AC.

Kecepatan tumbuh benih koro pedang yang terdapat pada ruang kamar dan ruang ber-AC tidak berbeda nyata selama periode simpan 1 dan 2 bulan. Kecepatan tumbuh benih yang disimpan dikedua ruangan mulai berbeda pada periode simpan 3 bulan. Kecepatan tumbuh benih koro yang disimpan di ruang kamar lebih tinggi dibandingkan ruang ber-AC pada periode simpan 3, 4, dan 6 bulan. Hasil pengujian tolok ukur keserempakan tumbuh juga memperlihatkan bahwa $\mathrm{K}_{\mathrm{ST}}$ ruang kamar lebih tinggi dibandingkan $\mathrm{K}_{\text {ST }}$ ruang ber-AC pada periode 2, 3, dan 4 bulan simpan.

Penyimpanan benih di ruang ber-AC pada periode simpan 6 bulan dengan hasil DB $46.78 \%$, IV $1.56 \%$, dan $\mathrm{K}_{\mathrm{ST}} \quad 6.89 \%$ (Tabel 3) memperlihatkan bahwa benih berkecambah dengan lambat. Indeks vigor ditentukan dengan persentase kecambah normal pada hitungan pertama (hari ke-5 pengecambahan). Hal ini memperlihatkan hanya $1.56 \%$ benih dari 50 benih yang tumbuh menjadi kecambah normal pada hitungan pertama, dan sisanya $45.22 \%$ pada hari ke-6 dan ke-7.

Pengaruh Jenis Kemasan terhadap Kadar Air, Potensi Tumbuh Maksimum, Viabilitas, dan Vigor Benih Koro Pedang

Kadar air benih yang disimpan dengan karung plastik paling tinggi dibandingkan dengan kadar air benih yang disimpan dengan jerigen plastik dan plastik PP selama periode 1 - 6 bulan simpan. Benih yang disimpan dengan kemasan karung plastik memiliki kadar air mencapai $12 \%$ sedangkan pada jerigen plastik dan plastik PP 
sekitar 9\% . Karung plastik adalah kemasan yang paling porus diantara jerigen plastik dan plastik $\mathrm{PP}$, hal inilah yang menyebabkan KA benih koro pedang langsung meningkat dari $9.31 \%$ (Tabel 1) menjadi $12.26 \%$ (Tabel 4) pada periode simpan 1 bulan.

Tujuan dari pengemasan benih adalah mencegah peningkatan kadar air benih karena pengaruh lingkungan. Peningkatan kadar air benih dapat terjadi karena kondisi lingkungan yang memiliki RH yang tinggi. Salah satu faktor yang dapat meningkatkan laju deteriorasi adalah peningkatan kadar air benih, sehingga dibutuhkan bahan kemasan yang dapat menghambat peningkatan kadar air benih (Kuswanto, 2003). Peningkatan kadar air yang cepat pada benih yang disimpan dengan karung plastik dikhawatirkan akan mempercepat laju deteriorasi benih, sehingga benih tidak bisa disimpan dalam jangka waktu yang panjang.

Jenis kemasan memberikan pengaruh yang nyata terhadap potensi tumbuh maksimum hanya pada periode simpan 2 bulan. Benih yang disimpan dengan karung plastik dan plastik PP memiliki PTM lebih tinggi dibandingkan dengan benih yang disimpan dengan jerigen plastik. Potensi tumbuh maksimum benih koro pedang yang sudah berumur 15 bulan setelah pemanenan ini masih tinggi, dengan kisaran 93.00\% $100.00 \%$. Potensi tumbuh maksimum yang masih tinggi, sedangkan daya berkecambah yang sudah turun pada periode simpan 6 bulan mengindikasikan semakin banyak benih yang tumbuh menjadi kecambah abnormal.

Variasi kecambah abormal pada hasil pengujian penyimpanan lebih sedikit dibandingkan kecambah abnormal hasil percobaan pengusangan cepat fisik. Kecambah abnormal pada percobaan kedua didominasi kecambah yang hipokotil belum memiliki panjang kurang dua kali ukuran benih dan kulit benih masih membungkus kotiledon. Kecambah abnormal karena busuk tidak ditemukan pada percobaan kedua. Berbeda dengan percobaan pertama yang kecambah abnormalnya sebagian besar karena busuk, akar primer tidak ada atau busuk, dan kotiledon busuk.

Daya berkecambah benih koro pedang dengan perlakuan jenis kemasan tidak berbeda nyata hingga periode simpan 5 bulan. Benih koro pedang yang disimpan dengan kemasan karung plastik nyata lebih tinggi dibandingkan dengan benih yang disimpan dengan kemasan jerigen plastik, tetapi tidak berbeda nyata dengan benih yang disimpan dengan kemasan plastik PP pada periode simpan 6 bulan (Tabel 4). Berbeda dengan beberapa hasil penelitian yang menyebutkan semakin tinggi kadar air dan semakin porus jenis kemasan yang digunakan maka viabilitasanya semakin rendah. Penelitian Tatipata (2008) daya berkecambah benih kedelai menurun seiring dengan semakin tinggi kadar air benih awal dan semakin porus kemasan. Persentase daya berkecambah dengan jenis kemasan karung plastik pada periode simpan 6 bulan satu-satunya yang di atas batas minimal DB benih koro pedang. Berdasarkan Dirjen TP (2009) batas minimal daya berkecambah benih koro pedang adalah $70 \%$.

Benih yang disimpan dengan karung plastik memiliki nilai BKKN paling tinggi dibandingkan dengan kemasan jerigen plastik tetapi tidak berbeda dengan plastik PP pada periode simpan 3 sampai 5 bulan. Berat kering kecambah normal yang disimpan dengan ketiga jenis kemasan tersebut cenderung mengalami penuruunan. Penurunan yang sangat signifikan terjadi pada periode penyimpanan 6 bulan (Tabel 4). Hutahaean (2008) menyatakan bobot kering kecambah normal terus menurun seiring semakin lamanya penyimpanan benih kedelai. Daya berkecambah benih tidak akan meningkatakan bobot kering kecambah, karena pada saat berkecambah tanaman belum melakukan fotosintesis namun hanya menggunakan cadangan makanan dari benih tersebut. Bobot kering kecambah normal dapat meningkat jika sudah terjadi aktivitas daun dalam fotosintesis.

Pengaruh jenis kemasan terhadap vigor benih koro pedang diamati dengan tolok ukur indeks vigor, kecepatan tumbuh, dan keserempakan tumbuh. Kecepatan tumbuh benih dengan kemasan karung plastik dan plastik PP lebih tinggi dibandingkan dengan jerigen plastik pada periode simpan 2 bulan. Periode 3 - 5 bulan simpan, benih yang disimpan dengan karung plastik memiliki kecepatan tumbuh paling tinggi dibandingkan benih yang disimpan dengan kemasan jerigen plastik dan plastik PP (Tabel 4). Tabel 4 menunjukkan keserempakan tumbuh benih yang disimpan dengan karung plastik juga paling tinggi pada periode simpan 1 - 2 bulan dan 3 - 4 bulan. Hasil ini menunjukkan bahwa benih yang disimpan dengan karung plastik memiliki vigor individual dan vigor lot benih yang lebih tinggi dibandingkan benih yang disimpan dengan jerigen plastik dan plastik PP. Pernyataan ini didukung oleh Widajati et al. (2012) yang menyatakan bahwa kecepatan tumbuh benih mencerminkan vigor indvidual benih dikaitkan dengan waktu, sedangkan keserempakan tumbuh benih menunjukkan vigor suatu lot benih. 
Tabel 4. Pengaruh jenis kemasan terhadap kadar air, potensi tumbuh maksimum, viabilitas, dan vigor benih koro pedang selama periode simpan 1-6 bulan

\begin{tabular}{|c|c|c|c|c|c|c|c|}
\hline \multirow[b]{2}{*}{ Kemasan } & \multicolumn{7}{|c|}{ Tolok ukur ${ }^{\mathrm{a}}$} \\
\hline & $\begin{array}{l}\text { KA } \\
(\%)\end{array}$ & $\begin{array}{l}\text { PTM } \\
(\%)\end{array}$ & $\begin{array}{l}\text { DB } \\
(\%)\end{array}$ & BKKN (g) & $\begin{array}{l}\text { IV } \\
(\%)\end{array}$ & $\begin{array}{c}\mathrm{K}_{\mathrm{CT}} \\
\left(\% \text { etmal }^{-1}\right)\end{array}$ & $\begin{array}{l}\mathrm{K}_{\mathrm{ST}} \\
(\%)\end{array}$ \\
\hline & & & & 1 bulan & & & \\
\hline Karung plastik & $12.26 \mathrm{a}$ & 99.00 & 98.00 & $24.49 \mathrm{a}$ & $52.33 \mathrm{a}$ & 17.82 & $65.00 \mathrm{a}$ \\
\hline Jerigen plastik & $9.21 \mathrm{~b}$ & 100.00 & 98.33 & $22.30 \mathrm{ab}$ & $40.67 \mathrm{ab}$ & 17.16 & $61.67 \mathrm{~b}$ \\
\hline Plastik PP & $8.77 \mathrm{~b}$ & 98.67 & 94.00 & $\begin{array}{l}20.12 \mathrm{~b} \\
2 \text { bulan }\end{array}$ & $35.67 \mathrm{~b}$ & 17.24 & $37.33 \mathrm{c}$ \\
\hline Karung plastik & $12.50 \mathrm{a}$ & $100.00 \mathrm{a}$ & 94.00 & $20.99 \mathrm{a}$ & $49.17 \mathrm{a}$ & $17.13 \mathrm{a}$ & $52.33 \mathrm{a}$ \\
\hline Jerigen plastik & $9.24 \mathrm{~b}$ & $98.67 \mathrm{~b}$ & 90.67 & $18.58 \mathrm{~b}$ & $34.67 \mathrm{~b}$ & $15.87 \mathrm{~b}$ & $33.00 \mathrm{~b}$ \\
\hline Plastik PP & $9.06 \mathrm{~b}$ & $99.67 \mathrm{a}$ & 97.67 & $\begin{array}{l}19.9 \mathrm{ab} \\
3 \text { bulan }\end{array}$ & $31.33 b$ & $16.88 \mathrm{a}$ & $29.67 b$ \\
\hline Karung plastik & $12.29 \mathrm{a}$ & 100.00 & 95.33 & $23.75 \mathrm{a}$ & $53.33 \mathrm{a}$ & $17.46 \mathrm{a}$ & 62.33 \\
\hline Jerigen plastik & $9.00 \mathrm{~b}$ & 100.00 & 92.00 & $21.51 \mathrm{~b}$ & $30.67 \mathrm{~b}$ & $16.19 b$ & 51.67 \\
\hline Plastik PP & $8.97 \mathrm{~b}$ & 99.67 & 93.00 & $\begin{array}{r}22.15 \mathrm{ab} \\
4 \text { bulan }\end{array}$ & $29.33 b$ & $16.33 b$ & 49.67 \\
\hline Karung plastik & $11.80 \mathrm{a}$ & 98.67 & 95.00 & $26.81 \mathrm{a}$ & $53.33 \mathrm{a}$ & $17.42 \mathrm{a}$ & $46.00 \mathrm{a}$ \\
\hline Jerigen plastik & $7.95 \mathrm{~b}$ & 98.33 & 87.00 & $22.56 \mathrm{~b}$ & $24.00 \mathrm{~b}$ & $15.05 b$ & $22.67 b$ \\
\hline Plastik PP & $8.69 b$ & 99.00 & 91.67 & $\begin{array}{r}24.04 \mathrm{ab} \\
5 \text { bulan }\end{array}$ & $28.33 b$ & $16.05 b$ & $25.00 \mathrm{~b}$ \\
\hline Karung plastik & $12.11 \mathrm{a}$ & 98.33 & 92.00 & $20.85 \mathrm{a}$ & $29.00 \mathrm{a}$ & $16.25 \mathrm{a}$ & $31.67 \mathrm{a}$ \\
\hline Jerigen plastik & $8.60 \mathrm{~b}$ & 96.00 & 89.67 & $18.92 b$ & $13.00 \mathrm{~b}$ & $14.78 b$ & $13.33 b$ \\
\hline Plastik PP & $8.98 \mathrm{~b}$ & 98.00 & 89.00 & $\begin{array}{r}19.09 \mathrm{ab} \\
6 \text { bulan }\end{array}$ & $11.33 b$ & $14.78 b$ & $8.33 \mathrm{~b}$ \\
\hline Karung plastik & $12.36 \mathrm{a}$ & 96.00 & $73.00 \mathrm{a}$ & 12.43 & 5.67 & 11.45 & 15.33 \\
\hline Jerigen plastik & $8.91 \mathrm{~b}$ & 93.00 & $48.67 \mathrm{~b}$ & 8.63 & 1.33 & 7.85 & 5.67 \\
\hline Plastik PP & $9.29 b$ & 94.67 & $58.67 \mathrm{ab}$ & 10.66 & 2.33 & 9.53 & 13.00 \\
\hline
\end{tabular}

Tingginya vigor benih yang disimpan dengan karung plastik juga didukung dari hasil tolok ukur indeks vigor. Benih yang disimpan di dalam karung plastik nyata lebih tinggi daripada kemasan jerigen plastik dan plastik PP pada periode simpan 2 - 5 bulan (Tabel 4).

\section{KESIMPULAN}

Pengusangan cepat fisik dengan menggunakan APC IPB 77-1 MMM terhadap benih koro pedang mampu meningkatkan kadar air benih, menurunkan PTM, viabilitas dan vigor benih. Peningkatan kadar air, penurunan PTM, viabilitas dan vigor benih cenderung seiring dengan peningkatan lama penderaan.

Penyimpanan benih di ruang suhu kamar menghasilkan kadar air benih lebih tinggi daripada penyimpanan di ruang ber-AC. Kecenderungan yang sama ditunjukkan oleh viabilitas dan vigor benih. Benih yang disimpan dengan karung plastik menghasilkan kadar air tertinggi selama penyimpanan. Benih yang disimpan dengan karung plastik memiliki viabilitas dan vigor benih yang tinggi pula. Viabilitas dan vigor benih koro pedang tururn drastis pada periode simpan 6 bulan yang disimpan pada kedua ruang dan dengan 3 jenis kemasan. Hal ini mengindikasikan benih koro pedang tersebut sudah tidak bisa disimpan lebih lama lagi.

\section{DAFTAR PUSTAKA}

Ashwort, S. 2002. Seed to Seed Second Edition, Seed Saving and Growing Techniques for Vegetable Gardeners. Whealy K, editor. United Stated of America (US): Seed Savers Exchange.

Badriah, R. 2012. Pemanfatan alat pengusangan cepat (APC) tipe IPB-1 MM untuk pendugaan vigor daya simpan benih jagung (Zea mays L.) [skripsi]. Bogor (ID): Institut Pertanian Bogor.

Baktisari, A. 2011. Keragaman karakter terkait vigor daya simpan benih kedelai (Glycine $\max$ L. Merill) [skripsi]. Bogor (ID): Institut Pertanian Bogor. 
[Dirjen TP] Direktorat Jendral Tanaman Pangan. 2009. Persyaratan dan tatacara sertifikasi benih bina tanaman pangan. Dalam Widajati E, Murniati E, Palupi ER, Suharsi TK, Suhartanto MR, Qadir A. 2012. Dasar Ilmu dan Teknologi Benih. Bogor (ID): IPB Press.

[Dirjen TP] Direktorat Jendral Tanaman Pangan. 2013. Pedoman Teknis Pengelolaan Produksi Kacang Tanah, Kacang Hijau dan Aneka Kacang Tahun 2013 [Internet]. [diunduh 2013 Des 28]. Tersedia pada: http: //pusdatin.setjen.deptan.go.id/ditjentp/files/ PednisKac_2013.pdf.

Hutahaean, J.E. 2008. Viabilitas benih kedelai (Glycine $\max (\mathrm{L}$.$) Merr) dengan varietas$ dan kemasan yang berbeda pada beberapa ruang penyimpanan [tesis]. Medan (ID): Universitas Sumatera Utara.

Imaniar, A. 2012. Pemanfaatan alat pengusangan cepat (APC) IPB \&\&-1 MM untuk pendugaan vigor daya simpan benih kedelai ( Glycine $\max$ (L.) Merr.) [skripsi]. Bogor (ID): Institut Pertanian Bogor.

Kuswanto, H. 2003. Teknologi Pemrosesan, Pengemasan, dan Penyimpanan Benih. Yogyakarta (ID): Kanisius.

Muchtar, S.D., Widajati, E., Giyanto. 2014. Pelapisan benih menggunakan bakteri probiotik untuk mempertahankan viabilitas benih jagung manis (Zea mays saccharata Sturt) selama penyimpanan. Bul Agrohorti 1(4):26-33.
Mustika, S., Suhartanto, M.R., Qadir, A. 2014. Kemunduran benih kedelai akibat pengusangan cepat menggunakan alat IPB 77-1 MM dan penyimpanan alami. Bul Agron. 2(1):1-10.

[Puslitbangtan] Pusat Penelitian dan Pengembangan Tanaman Pangan. 2007. Policy Brief Potensi Kacang Koro Pedang sebagai Pengganti Kedelai untuk Diversifikasi Pangan [Internet]. [diunduh 2013 Nov 20]. Tersedia pada: http://www. puslittan.bogor.net/index.php?bawaan=berit a/fullteks_berita\&\&kunci=koro+pedang\&k od $=$ Cari\&id $=96$.

Rahayu, E., Widajati, E. 2007. Pengaruh kemasan, kondisi ruang simpan, dan periode simpan terhadap viabilitas benih caisin (Brassica chinensis L.) Bul Agron. 35(30):191-196.

Saleh, M.S., Wardah. 2010. Perkecambahan benih aren dalam kondisi terang dan gelap pada berbagai konsentrasi $\mathrm{GA}_{3}$. J Agrivigor 10 (1):18-25.

Syarovy, M., Haryati, Sitepu, F.E.T . 2013 Pengaruh beberapa tingkat kemasakan terhadap viabilitas benih tanaman rosela (Hibiscus sabdariffa L.). Agroekoteknologi 1(3): 544-559.

Tatipata, A. 2008. Pengaruh kadar air awal, kemasan dan lama simpan terhadap protein membran dalam mitokondria benih kedelai. Bul Agron. 36(1):8-16.

Widajati, E., Murniati, E., Palupi. E.R., Suharsi, T.K., Suhartanto, M.R., Qadir, A. 2012. Dasar Ilmu dan Teknologi Benih. Bogor (ID):IPB Press. 